\title{
Negotiating gender constraints in international audit firms in Saudi Arabia: Exploring the interaction of gender and religion *
}

*Dr. S. Sian (corresponding author)

Queen Mary, University of London

School of Business and Management

Francis Bancroft Building

Mile End Road

London E1 4NS

United Kingdom

Email: s.sian@qmul.ac.uk

Dr. T. Wright

Queen Mary, University of London

School of Business and Management Francis Bancroft Building

Mile End Road

London E1 4NS

United Kingdom

Email: T.Wright@qmul.ac.uk

Dr. D. Agrizzi

University of Essex

Essex Business School

Gateway Building, Elmer Approach

Southend-on-Sea SS1 1LW

United Kingdom

Email: dila.agrizzi@essex.ac.uk

Dr. A. Alsalloom

King Saud University

College of Business Administration

Riyadh 12372

Saudi Arabia

Email: aalsallom@ksu.edu.sa 


\begin{abstract}
The adoption of religious nationalism as a public project by the Saudi state continues to intimately shape the experiences of Saudi women, despite recent initiatives facilitating the participation of women in the workforce. Through interview-based evidence, the paper shows how patriarchal societal norms and practices rooted in a particular interpretation of Islam and enshrined in legislation are transported into the workplace and impact upon the daily lives of Saudi women auditors. Although various barriers to the progression of women auditors are already identified in the accounting and gender literature, our study provides additional insights into how the profession in Saudi Arabia takes a very distinctive gendered form due to the interaction of gender with religious and cultural norms. Additionally, our evidence highlights the role of the global audit firms, particularly the predominantly male audit managers and partners, in adapting their diversity management practices to navigate the constraints on female auditors in the Saudi context. We find evidence of pervasive inequality and the re-segregation of the Saudi female auditing workforce into 'woman-friendly' areas, with potentially damaging effects on career progression.
\end{abstract}

Key words: Audit firms; gender; accounting profession; religious nationalism; Saudi Arabia 


\section{Introduction}

Despite the focus on gender equality in the twenty-first century and the feminisation of the accounting profession, a strong thread running through the gender and accounting-related literature continues to be the inequalities and barriers faced by women in professional accountancy. These studies are predominantly set within a European or western context and are underpinned by a liberal feminist approach. Responding to Gallhofer's comments that this body of research overlooks "considerations of class, race and culture" (Gallhofer, 1998 p.355), other authors have examined the dual levers of discrimination based on race and gender (Hammond, 2002, 1997; Kim, 2004a, 2004b; McNicholas et al., 2004). More recently, this field has also profited from contributions from non-western settings. For instance, Komori (2008) highlights the case of women in the Japanese accounting profession and Kamla (2012) introduces the case of Syrian women accountants and shows how the practice of veiling has allowed them to negotiate greater opportunities for access to work within a patriarchal context. Without widening the field to address the experiences of women in other cultural contexts, there remains a risk of compiling an incomplete picture of the nature of the relationship between gender and accounting (Komori, 2007). These prior works also show how the role and position of the accounting profession remains shaped by local historic and socio-cultural factors (Cooper and Robson, 2006), despite the significant part globalisation has played in the spread of the large global audit firms (Barrett et al., 2005).

Firmly located within this literature, this study draws attention to the distinctive experiences of women auditors in the large global audit firms in Saudi Arabia. Here, political ideology and strict Islamic rulings penetrate the profession with far-reaching consequences for the women employed therein. This paper adds to the limited body of accounting-related research set in Saudi Arabia ${ }^{1}$ and examines how politics and religion combine to create rules and norms that translate into, often complicated, negotiations for professional women auditors on a daily basis. Although recent legislative changes have facilitated greater participation of women in society, once within the workplace women encounter a variety of obstacles not previously described in accounting-

\footnotetext{
${ }^{1}$ Accounting-related studies set in the Kingdom of Saudi Arabia (KSA) are few. Mihret et al. (2017) examines how SOCPA (Saudi Organization for Certified Public Accountants) secured legislation to control standard setting and entry to professional practice. There are also studies which focus internal audit: Woodworth and Said, 1996; Al-Twaijry et al., 2004 and Abdulrahman et al., 2003. In their study of external audit, Haniffa and Hudaib (2007) focussed on the audit expectations gap in KSA and Hudaib and Haniffa (2009) looked at auditor independence in KSA.
} 
related literature. Through interview-based evidence, we show how the gendered norms of Saudi society are transported into the workplace and inhibit the capacity of women auditors to do their jobs effectively and impact on their career progression. We note that the barriers contributing to gender inequality in professional accountancy in western settings are also identified within the profession in Saudi Arabia although they take a very distinctive gendered form, shaping the experience of women auditors in very particular ways.

Our study sets out to make a contribution at several levels. Firstly, it responds to calls for examinations of gender in the profession in diverse cultural settings (Komori, 2008), extending the profession-related literature in Islamic settings and, in particular, on women in accountancy in the Arab world, addressing the gap identified by Kamla (2012). Secondly, it is one of the first studies to provide data on the experiences of women within the auditing function of the large global accounting firms in Saudi Arabia. In doing so, the study contributes valuable empirical evidence of how women experience and overcome barriers of gender inequality at work in the understudied Middle East context, where gender, culture and religion are topics that are complex, sensitive and difficult to research (Hodges 2017; Syed et al, 2018). Thirdly, the paper not only shows how women auditors experience and negotiate the constraints that they face, but also illustrates the important role of male managers and colleagues in accommodating the specific gendered requirements for women's work. Fourthly, given the prominence of global accounting firms in Saudi Arabia and the policy of Saudiization which requires greater participation of Saudi nationals (men and women) in the workforce, the paper offers insights into how these global firms are adapting in order to employ increasing numbers of local women. Finally, it adds to scholarship on gender and diversity in contemporary professions and professional services more broadly, where there is a need for further research given their increasing economic and occupational significance (Muzio and Tomlinson, 2012).

At the theoretical level, previous studies in the accounting-related literature employ forms of critical feminism, with many tending to treat women as a homogenous group, focusing mainly on gender inequalities in the profession. In this study, we draw attention to the complexity of the social construct of gender in a context where politics and religion shape gender norms in particular ways. To the western eye, the position of women within the patriarchal society of Saudi Arabia is one of inequality and subordination. However, western understandings of gender inequality as rooted solely in Islamic teachings can lead to an approach - including from feminists - that seeks to 'rescue' or 'save' Muslim women through adopting 'western values', 
thus denying them agency and voice (Abu-Lughod, 2013). We seek, here, to understand the complex relationship between politics, religion and gender in the country, drawing initially on Al-Rasheed's analysis of the roots of gender inequality in the politically-motivated embrace of Wahhabism as a means of unifying the Saudi state. ${ }^{2}$ The adoption of religious nationalism as a public project by the state is pervasive today, intimately shaping the experiences of Saudi women, despite recent changes in Saudi society facilitating the participation of women in the workforce. Following other studies that foreground the experiences of Saudi women in the workplace and in the professions (Hodges, 2017; Syed et al, 2018,), we present the voices of pioneering Saudi women auditors who are entering the profession in a period of change.

Ultimately, we find a particular and distinctive form of discrimination faced by women auditors in our study, which permits certain forms of employment but within very specific gendered constraints. The particular research setting within the Big 4 global audit firms is highly pertinent, as this produces both opportunities and constraints for women auditors, deriving from the interaction of corporate values and expectations with the gendered religious and social norms in operation in the Saudi context. We show how women perceive the constraints affecting their work opportunities, but also the ways in which they accommodate these in order to pursue their careers in auditing. Furthermore we reveal the role of male managers as guardians 'in loco parentis' to facilitate the participation of women auditors and their role in both maintaining limitations and opening up opportunities for women auditors in developing their careers.

The paper is presented as follows. In the following section, we examine the existing gender and accountancy literature and consider the opportunities presented by this study for extending this body of work. In section 3, we trace the roots of gender inequality in Saudi Arabia and its manifestation and then, in section 4 , focus on political initiatives to improve the position for women in the workplace and the policy of Saudiization in relation to the labour market in general, and accountancy in particular. We explain the methods employed to gather data from in-depth interviews, before presenting our empirical findings under the four themes of: guardianship and family honour; mobility restrictions; dress codes; and negotiating the client relationship. Finally, we draw conclusions.

\footnotetext{
2 "Wahhabism" is the official and dominant form of Sunni Islam in Saudi Arabia. It is an Islamic religious movement founded by Muhammad ibn Abd al-Wahhab.
} 


\section{Gender and accountancy}

An overarching theme of the extant gender and accountancy literature continues to be the existence of gendered norms, structures and practices within accounting firms that constrain the progression of professional women (Ciancanelli et al. 1990; Adapa et al. 2016; Dambrin and Lambert 2008; Kornberger et al. 2010; Windsor and Auyeung 2006; Broadbent and Kirkham 2008). A number of studies have presented historical insights into the entry of women into the profession and emphasised how gender discrimination was built into work structures and practiced (Crompton, 1987; Kirkham, 1992; Lehman, 1992; Loft, 1992; Roberts and Coutts, 1992; Kirkham and Loft, 1993; Shackleton, 1999). Once within the profession, the literature shows that women still face barriers to participation and progression and these can be classified into three distinct groups: firstly, barriers related to traits and identity; secondly, barriers related to social stereotypical attitudes perpetuated within corporate cultures and, thirdly, barriers related to organisational policies and practices.

The first group includes studies which show that the obstacles that women face within the profession relate to criteria specific to women, including professional identity. Some liberal feminist studies have argued that the obstacles faced are related to personality traits, motivation, know-how, skills and lack of self-confidence (Barker and Monks, 1998; Hunton et al., 1996; Dambrin and Lambert, 2012). A more recent stream of research has focussed on professional identity. Professional embodiment involves meeting the expectations of clients and fellow professionals by 'looking the part' in terms of dress code, socialisation and behaviour, credibility and presenting oneself with gravitas and appropriate body language (Anderson-Gough et al., 2005; Fearfull and Kamenou, 2006; Kamla, 2012; Haynes, 2012; Khalifa, 2013). The professional and organisational discourses within accounting firms form the socialisation processes and exercise a significant degree of institutional power in the shaping of the individual employee and his/her professional identity (Anderson-Gough et al., 2005). The literature suggests that such professional embodiment may clash with other forms of the gendered embodied self, such as pregnancy and motherhood.

The second group includes studies on the social stereotypes perpetuated within corporate cultures (Dambrin and Lambert, 2012). Studies have shown that professional accountancy is principally a 'male-dominated hierarchy' (Dwyer and Roberts, 2004; Anderson-Gough et al., 2005). Others have shown that accountancy has been characterised as 
rational/technical/intellectual and, therefore, an essentially 'male' occupation (Kirkham, 1992; Emery et al., 2002), in which both men and women adopt "masculine" stereotypes as conditions of moving up the corporate hierarchy (Maupin and Lehman, 1994). Similarly, women stereotyped as favouring family life, working part-time or not doing extra hours are perceived as lacking commitment (Kirkham, 1992; Kirkham and Loft, 1993; Barker and Monks, 1998) and motherhood, in particular, is associated with restricting or even halting opportunities for career progression in accounting firms, specifically to partnership level (Windsor and Auyeung, 2006; Dambrin and Lambert, 2008, 2012). In her study, Lupu notes that the approved routes for progression were "constructed in such a way as to be more suitable for males, than the majority of females, especially mothers" (Lupu 2012, p.352) and others have found that for those remaining in the profession, jobs which are 'less prestigious' and financially rewarding, such as taxation, are seen as a 'mummy track' reserved for women with family constraints (Khalifa, 2013; Lupu, 2012).

A related third stream of research examines barriers and gender imbalance related to organisational policies and practices. These include gender discrimination in the formal processes of the firm such as recruitment, remuneration, type of job assignments, performance appraisal and promotion (Lehman, 1992; Kirkham and Loft, 1993; Reed et al., 1994; Barker and Monks, 1998; Anderson-Gough et al., 2005; Whiting, 2012). In addition, gender imbalance is also embedded in the informal processes which constitute the culture of the firm in the form of values, beliefs and norms (Anderson-Gough et al., 2005). Although women now succeed educationally in accountancy and have equal representation at the entry level, they still experience inequalities in their advancement as they hit the metaphorical 'glass ceiling', in common with other professions (Broadbent and Kirkham, 2008; Ciancanelli et al., 1990; Roberts and Coutts, 1992; Loft, 1992). A specific feature of accounting and auditing is the auditor-client relationship, which allows the client to act as a regulating force in defining the provision of services (Anderson-Gough et al., 2000; Haynes, 2010; Kornberger et al., 2010; Gammie and Whiting 2013) and to legitimise discrimination against women in audit firms (Loft, 1992; Anderson-Gough et al., 2005; Kornberger et al., 2010; Khalifa, 2013). Working conditions in the profession, combined with the impact of alternative/flexible work arrangements, are also organisational processes which affect women's career progression (Barker and Monks, 1998; Whiting, 2008; Kornberger et al., 2010; Gallhofer et al., 2011), as evidenced by studies highlighting the rarity of women at the highest levels in the accounting profession (Dambrin and Lambert, 2008; Whiting, 2008, 2012). 
This literature effectively shines a light on the position of professional women accountants and the barriers that they face in audit firms within a western setting, building on the thread of 'feminist liberal thought', that privileges women who are white, Western, middle-class and educated (Gallhofer, 1998). ${ }^{3}$ It is a body of work that is underpinned by a view of feminism that, at its heart, calls for equality with professional male accountants with similar qualifications and experience. Studies concerning women in non-western contexts have similarly outlined the obstacles women experience within the accounting profession, although local historic and socio-cultural contexts play a role in shaping their experiences (Komori, 2008; Kamla, 2012). Thus, although professional identity, a male-dominated hierarchy, temporal constraints, barriers to inclusion and progression are all themes to be found in both western and non-western settings, the way in which women experience these barriers is very different and is closely linked to the internal dynamics of the society in which they live. The case of Saudi Arabia presents a real opportunity to extend gender and accounting-related research in several ways. Firstly, issues of professional identity for Saudi women auditors are so interconnected with their personal belief system and societal forces that their experience of dress codes, professional socialisation and client relations are entirely different from women auditors in the west. Secondly, themes related to working hours and flexibility to be found in the literature are exacerbated in Saudi Arabia because of the mobility restrictions and the need for 'protection' and 'honour' that women auditors encounter. Thirdly, whilst a thread of the extant literature has focussed on the entry, acceptance and progression of women in the profession, in the case of Saudi Arabia strict male guardianship laws have created a set of barriers for Saudi women auditors not encountered in the West - a woman cannot even work without the consent of her guardians. Finally, the extant literature is underpinned by an essentially liberal (and critical) feminist position that seeks equality for the sexes through political and legal reform. In this study, alternative underpinning views of feminism are presented as a means of understanding the experiences of our participants. We introduce to the accounting literature the notion of Islamist feminism and secular feminism (Karam, 1998). The former seeks to interpret the religious texts through a feminist perspective, valuing women's difference and dignity and seeking the equality of women and men within the constraints of their interpretation of the Quran. The latter, on the other hand, adopts the discourse of

\footnotetext{
${ }^{3}$ Exceptions (in a western setting) include studies on black American women in the profession by Hammond, 2002, 1997; work on women of Chinese origin in New Zealand by Kim (2004a, 2004b); McNicholas et al's .,2004 paper on Maori women in New Zealand; Fearfull and Kamenou (2006) on ethnic minority women in Britain.
} 
promoting gender equality within secular Muslim society. ${ }^{4}$ Neither of these align easily with the liberal feminist discourse permeating the extant gender and accountancy literature. In the next section we proceed with this theme and examine the roots of religious nationalism in the Saudi state and its impact on the everyday lives of women.

\section{Religious nationalism: A framework for exploring gender inequality in Saudi society}

The position of women in Saudi Arabia is one of exclusion on a number of levels: social, economic, political and legal. The most recent Global Gender Gap Report (2018) places Saudi Arabia overall at position 141 out of the 149 counties assessed by their overall Gender Gap score. Although the country is ranked at number 93 when it comes to educational attainment for women, it is ranked at 143 for labour force participation (Zahidi et al. 2018). The Report notes that Saudi Arabia is one of the four worst-performing countries for the participation of women in managerial positions, at less than 7\% (alongside Egypt, Yemen and Pakistan). Gender inequality is, therefore, deeply embedded in Saudi society and in this section we examine its causes in the complex relationship between politics, religion and gender.

\section{The interaction of gender, politics and religion in Saudi society}

According to Madawi Al-Rasheed (2013), the position of women in contemporary Saudi Arabia is rooted in historical alliances formed by the Wahhabi tradition and its ideologues as the Saudi state formed. In 1932, the Al-Saud family unified the disparate tribal regions, which lacked a common culture, to form a united state regulated by sharia law under the banner of Wahhabi Islam. The objective was to transform strong personal piety into a national public project with the aim of creating a religious and moral society $-\mathrm{a}$ form of religious nationalism. Wahhabiyya placed the family unit at the centre of society and women were considered to be central pillars of the family - although under the patriarchal authority of male members. Women were seen as key to the creation of a "pure society" in the new Saudi state and honouring them and safeguarding their protection were central tenets of religious nationalism. As Al-Rasheed puts it, this established: "an ideology of order in which women became boundary markers representing the authority of the nation" (Al-Rasheed, 2013, p.38). The result is a state strongly

\footnotetext{
${ }^{4}$ Islamist feminism is expressed in a single or paramount religiously grounded discourse taking the Quran as its central text. Muslim secular feminism draws on and is constituted by multiple discourses including secular nationalist, Islamic modernist, humanitarian/human rights and democratic (Badran, 2005, p.6).
} 
influenced by religious nationalism, alongside the remnants of historic tribalism, in which women are honoured and, at the same time, constrained and subordinated.

Al-Rasheed comments that women are educated ${ }^{5}$ only to become good mothers who "contribute to producing the obedient, homogeneous and pious nation" (Al-Rasheed 2013, p.20). In her writings on Saudi women, Doumato also notes that the "idealised Islamic woman" in this interpretation of Islam is one who is dedicated to "protecting the family and guarding 'traditional values' and Islamic morality" and has therefore has become a symbol of morality that defines national identity in Saudi Arabia (Doumato, 1992, p.4). Religious doctrines concerning the position of women were and continue to be enforced by the Wahhabi ulama (Islamic scholars who are the guardians and interpreters of religious knowledge, doctrine and law) through the issue of fatwas, which are religious pronouncements that are used to uphold the piety of the nation. As arbiters of the position of women in Saudi society, the ulama have issued pronouncements on various aspects of the lives of women in the country with the aim of maintaining their honour and protection (Sidani 2005). ${ }^{6}$ If women do not comply with such regulations, they can be detained or arrested by the "religious police", the Mutawa, which enforces Islamic social and moral norms (Al-Rasheed 2013). ${ }^{7}$ In addition to creating and upholding an openly pious society, such action also helps to distinguish Saudi society from other Islamic societies and the West, evoking a moral superiority (Doumato, 1992).

\section{The protection of women in Saudi society}

These interpretations of Islamic law by the ulama have imposed restrictions on Saudi women and have, to a considerable extent, influenced their choices and experiences (Sidani, 2005). An example of such an interpretation is family honour or dishonour and reputation (Mosquera et al. 2002; Del Castillo, 2003). In particular, compromising the chastity of female family members or any perceived or actual acts of impropriety committed by women taint her morality and that of the entire family (Arebi, 1994; Mosquera et al., 2002). Within this context, women

\footnotetext{
${ }^{5}$ The earliest formal education of girls can be dated to 1949, but the number of female schools grew from 15 in 1960 to 3,370 by 1988 (Al Rawaf et al., 1991).

${ }^{6}$ In 1971 the Higher Council of Ulama was established by royal decree to issue fatwas. There have been fatwas on a wide range of issues concerning women: marriage, divorce; driving; employment; the education of girls; appropriate clothing for women and the colour of it (black); segregation of the sexes; that men must be financially responsible for women and protect them; prohibiting entry to mosques during menstruation; wearing high heels (Al-Rasheed, 2013).

${ }^{7}$ From 1932, when the state was formed, the ulama and the state police worked together closely to enforce religious rulings. Since 2016, the powers of the Mutawa have been restricted and they must now only report such acts to the regular police force.
} 
are regarded as objects of family honour and, in practice, this is translated into a male culture of 'over-protecting' their female relatives, through physical concealment and/or veiling, in order to preserve the family's honour (Arebi, 1994; Jamjoom, 2010).

The Quranic verses relating to the modesty of women are ambiguous, and whilst some interpret certain verses as a requirement for veiling, the same are also cited to prove that Islam only requires women to dress modestly (Doumato 1991). In Saudi Arabia, the Wahhabi Islam interpretation requires that strict dress codes are observed in both private and public, including in the workplace, in accordance with Islamic Hijab guidelines. The guidelines state that women must wear the abāyah, which is a compulsory traditional black dress that covers the whole body. In addition, a scarf covers the hair and the niqāb is an optional black veil that covers the face, only leaving an opening for the eyes.

The protection of female honour is enshrined in the strict Guardianship Laws, derived almost entirely from interpretation of Islamic legal sources and reflected in the Basic Law of Governance, 1992 (Alharbi, 2015). Under these laws, Saudi women are required to gain permission from their male guardian to perform many daily activities, including enrolling at university, applying to and/or having a job, travelling inside or outside the country or filing a court case (Deif, 2008). Male family members are entirely financially responsible for female members, which has historically meant that women were essentially excluded from the labour market (Doumato, 1999; Elamin, \& Omair, 2010). ${ }^{8}$ The guardianship concept also gives rise to legislation that forbids women to physically mix with men (with the exception of those to whom a woman cannot be married - e.g. brother, father and son), imposing a system of gender segregation in almost all aspects of private and public life, including the workplace (Baki, 2004). Although the government agreed to abandon the guardianship rules recently, in practice the system is still in place (Syed et al, 2018). Segregation and patriarchal control (as with dress codes) are not derived from the literal word of the Quran, but rather from the Wahhabi interpretations of Islam and local established practices (Doumato 1992). It has been argued that women symbolise the religious values of the state, which views their control as increasingly important "because there are few other symbolic behaviours besides veiling and segregating

\footnotetext{
${ }^{8}$ Al-Rasheed (2013) notes that women have not only been excluded from the workplace but also in the domestic sphere. Rising oil revenues in the country resulted in the employment of domestic staff in wealthy families and Saudi women were relieved of domestic roles within the family in addition to being confined to the home as a means of "protection" (p.23).
} 
women that have such personal resonance and are also so readily enforceable" (Doumato 1999). ${ }^{9}$

\section{The state and religious nationalism}

Whilst the King controls the present-day political and economic affairs of the country, the conservative religious scholars retain responsibility for social stability, Islamic teachings and the country's identity. Although the King is the supreme ruler of the country, any attempts at reforms of gender inequality must negotiate the views of the religious scholars, whose "defence of the realm" may be needed at times of political crisis. ${ }^{10}$ Other social and cultural traditions also intersect with religion to shape the particular forms of gender inequality encountered in Saudi Arabia - such as formal and informal traditions stemming from Bedouin and tribal culture, as well as the importance of 'wasta' - a reliance on networks of relationships to gain advantages, including jobs and promotion, which disadvantages women (Aldossari and Robertson, 2016; Syed et al, 2018). Some argue that assertions, in particular from the West, that Islam is responsible for women's subordination are ahistorical and do not recognise that women's "inferior position results from cultural and social constructions by men and not from formulations in sacred texts" (Altorki 2000, p.233, cited in Hodges 2017). However, others believe that Islamic teachings are strongly enshrined within societal norms (Elamin \& Alomaim, 2011), with patriarchal traditions that grant men authority over women are engrained in Saudi society (Hamdan, 2005; Sidani, 2005; Mobaraki \& Söderfeldt, 2010). Religious, cultural and social norms are now so intertwined that it is often difficult to distinguish which rules originate from the social or cultural and which from the religious (Al Lily, 2011; Al Alhareth et al., 2015; Syed et al., 2018).

This general principle dictates that any reforms or developments should fall within certain acceptable boundaries (Gallagher \& Searle, 1985) and it is the case that even liberal sectors of Saudi society campaigning for greater freedoms tend not to contest the existing system, but rather seek to work within it (Doumato, 2000). This is particularly true for reforms addressing gender

\footnotetext{
${ }^{9}$ Daily prayer in the mosque can no longer be enforced. Most Saudis are not prepared to forgo the option of receiving interest payments on bank deposits. Drinking alcohol, taking drugs and eating pork are all symbolic behaviours, "but neither has quite the emotive effect as that of a man's power to divorce his wife at will or his authority to control where she goes and what she does" (Doumato 1999).

${ }^{10}$ The state can either overlook fatwas or support them, often for self-serving political reasons. In the 1960s the state adopted education for girls (acting against the ulama) in order to promote its own image as a progressive state. In the 1980 s the state sided with the ulama to restrict the movement of women in order to promote their image of piety (Doumato 1992; Al-Rasheed 2013).
} 
inequality and referred to by some writers as a form of Islamic feminism. Al Alhareth et al (2015, p.2) note that Islamic feminism seeks to work within the values of Islam, not against them, by offering social benefits in a culturally satisfactory and sustainable way to families through enhanced opportunities for daughters, sisters, wives and mothers. Gender reforms are further complicated by the fact that Saudi women are not a homogeneous group. Therefore, whilst more liberal groups of women look to the state to curtail religious opinions that exclude women and perpetuate gender inequalities, other Islamist groups of women look to the state to gain more rights whilst retaining strict Islamic traditions (see Al-Rasheed, 2013, p.30 for a more detailed discussion).

Saudi Arabia has a unique position amongst Islamic states. It was not colonised and the western influence is relatively recent. Therefore, religious nationalism was free to develop undisturbed and supported by the state in both public and private life (Doumato 1992). Saudi Arabia is also unique because wealth from oil has enabled the state to enforce regulations such as the physical gender segregation (using surveillance cameras) in all spheres of society and fund the creation of parallel institutions (such as the religious police). It is important to have an understanding of the rise and prominence of religious nationalism in Saudi Arabia and how it has penetrated the workplace, as this forms the context for the everyday lives of the women auditors in our study.

In the next section, we draw attention to recent political shifts that have resulted in increased freedom for women to access education and opportunities to participate in the workforce generally, and accountancy in particular, although within the strict constraints of religious nationalism.

\section{Reforms to counter gender inequality}

Despite the power of the religious scholars over the development of Saudi society, recently the state has acted to redress gender inequality for reasons of both external reputation and internal economic pressures. Externally, addressing gender inequality aids in the legitimisation of the state on the international stage and satisfies the expectations of foreign states, with which it trades, to address high levels of gender inequality. Internally, in response to economic concerns, the state has enacted a Saudiization policy. In the Fourth Development Plan (1985-1989), a key 
objective of the Saudiization policy under King Abdullah was replacing foreign workers from Pakistan, India, the Philippines and other Arab countries by under-employed Saudi nationals (Mihret et al., 2017). The Nitaqat Program is a specific Saudiization initiative for the private sector which categorises companies depending on current percentages of Saudi employees. Nitaqat requires private companies in most industries to ensure that at least $30 \%$ of employees are Saudi nationals. Foreign workers are classified as skilled (mostly Westerners with expertise in specialised industries) or unskilled and domestic workers (mostly from the Asian subcontinent or Africa). There was also external pressure from the International Labour Organization (ILO) and the World Trade Organization (WTO) to reform its labour laws (Mellahi, 2007; Ministry of Labour). ${ }^{11}$ The reforms focused on measures such as increasing women's employment as a means of meeting the Saudiization targets for local employment.

Under the previous King, this strategy encouraged firms to employ Saudi women in order to improve female participation in the workforce (Elamin \& Alomaim, 2011; Mobaraki and Söderfeldt, 2010) by applying a ratio of one female recruit for every two male counterparts. At the international level, three United Nations and ILO conventions promoting gender equality in the workforce were signed (AlMunajjed, 2010; Schlaffer \& Kropiunigg, 2011). At the national level, the Council of Ministers promulgated regulations in 2004 establishing female-only sections in government departments and introducing new training initiatives to accommodate female workers (Regulation No.(120) (12/4/1425H) of 23 May 2004). ${ }^{12}$ In addition, a ministerial decree included a detailed programme to promote women's employment (Decree No.120; 2010), directed at both the private and public sector. In 2006, new benefits for working women with regards to maternity and medical-care leave, nursery provisions, vacation time, and pensions were approved (AlMunajjed, 2006; 2010). However, despite these efforts gender inequality in the workforce remains an issue as many of these reforms were enacted despite general disapproval within Saudi society.

More recently, initiatives have been introduced as elements of the Saudi Vision 2030, announced on the $25^{\text {th }}$ April 2016 by Crown Prince Mohammad bin Salman (http://vision2030.gov.sa/en). The economic impetus for this development strategy is to reduce Saudi Arabia's dependence on

\footnotetext{
${ }^{11}$ http://portal.mol.gov.sa/ar/Pages/nitaqat.aspx

${ }^{12}$ This regulation also called for a decision to eliminate the need for approval from a male guardian, but this was deemed a step too far and was not included in the final legislation.
} 
oil, to diversify its economy and develop sectors such as health, education, transport, renewable energy and tourism. A key part of the development plan is the utilisation of local talent, particularly women.

The result of such reforms and strategies has been a steady rise in the female labour force participation rate (the percentage of female workers in the population aged 15 and over) from 14\% in 1990 to $22 \%$ in 2017 (https://data.worldbank.org/indicator). However, the proportion of women in the workforce remains low in comparison to the significant numbers of women now entering higher education. Although roughly equal numbers of men and women enter higher education (Source: Global Gender Gap Report 2018) ${ }^{13}$ and women accounted for nearly $60 \%$ of university graduates in 2016, only around 20\% entered the workforce after graduation (Young, 2016; Central Department for Statistics and Information; Gulf Labour Markets and Migration; National Bureau of Statistics - UAE Ministry of Economy). Tackling this lost contribution to the Saudi Arabian economy is a key priority for the new regime under the Saudi Vision 2030, which aims to increase women's participation rates to $30 \%$ by 2030 . Many of the women taking up employment do so in the public sector as these jobs are associated with higher status and offer shorter working hours and better benefits. The Saudi private sector is less attractive for women, since firms must comply with strict legal requirements for segregation. However, areas such as retail, banking, education and healthcare are increasingly important sectors for female employment (Doumato, 1999). Employment in the private sector is also growing and the number of Saudi women employed in the private sector rose from 30,000 in 2005 to just under 500,000 in 2015 (Kinninmont, 2017).

What these reforms have done is to instill hope for the next generation, as our Saudi-based coauthor put it: "Saudi women are familiar with the types of barriers they will face, and female university students' are becoming very hopeful that their lives will be different than those of their older female relatives". Although, the most recent Global Gender Gap Report shows that more women are participating in the labour force as a result of these changes (Zahidi et al., 2018, p.24), this study will show that, despite the encouraging the entry of women to the profession, gender inequality persists in the workplace in accountancy and audit.

\footnotetext{
13 In 2017, the rate of enrolment in higher education was 107 female students per 100 male students, based on the index for equal education opportunities between the sexes https://www.stats.gov.sa/ar/924
} 


\section{Female participation in the accounting profession in Saudi Arabia}

Despite the reforms, the accounting profession in Saudi Arabia has continued to be strongly maledominated and although women began to enter the profession in 2003, they remain a small minority. None of the Big 4 firms contacted responded to requests to confirm the number of women currently working for them. ${ }^{14}$ The SOCPA (Saudi Organization of Certified Public Accountants) fellowship exam ${ }^{15}$ was opened to women in 2003 (SOCPA, 2013) and by 2013, SOCPA fellowship holders included 8 female accountants (SOCPA, 2013). The Arabic pages of the SOCPA website state that there are currently 798 SOCPA members in total, of whom only 59 are female. ${ }^{16}$ The numbers are small because university qualifications combined with the impact of new governmental legislation have only very recently provided substantive access to the profession. Additionally, some women have taken the SOCPA examinations and qualified, but, according to several of our interviewees, have been unable to secure employment or have simply chosen not to. Although there are now female auditors, we present evidence showing how strict religious regulations have significant consequences for those embarking on careers in audit and the firms that employ them.

Like many other international organizations, the large accounting firms have signed up to various initiatives supporting diversity and the inclusion and progression of women in their workforce. ${ }^{17}$ In Saudi Arabia, in the wake of the release of the Saudi Vision 2030 and government edicts regarding the employment of women, the big international accounting firms have been recruiting women. In doing so, the firms execute their global gender diversity policies at the local level, enhance their symbolic capital, and seek to profit from the claimed 'business case for diversity' benefits of a more diverse labour force (Kirton and Greene, 2015). The outcome has been the

\footnotetext{
${ }^{14}$ Women now outnumber men on accountancy degrees but are still under-represented in the profession. In 2012 accounting graduates from King Saud University comprised 291 females and 121 males (KSU, 2012). One of the authors received confirmation from an un-named source that out of around 120 female employees working in KPMG in KSA, 40 were trainees within departments such as audit, consultancy and zakat and tax.

${ }^{15}$ The Fellowship examinations must be passed in order to qualify as a professional accountant in KSA and become a member of SOCPA (2018).

16 Source: http://socpa.org.sa/Fellowship-Authority/Fellowship-Holders.aspx

17 For example, EY were one of the first of the Big 4 to sign up to Paradigm for Parity (P4P) when it was launched in 2016. P4P aims for 50\% of the firm's senior leadership to be women by 2030. PWC have initiated The Female Board Mentoring Sponsorship for high performing female partners, which supports their goal of bringing more women through to senior leadership roles. All four of the big accounting firms have global policies on closing their gender pay gap.
} 
appearance and (limited) rise of women training as auditors and accountants within the Big 4. For instance, Kholoud Mousa was the first Saudi woman licensed to practice as a certified public accountant in the Kingdom (Arab News, 2010) and subsequently was the first female Audit Partner at KPMG Al Fozan \& Partners in June 2017 (https://home.kpmg.com/sa).

However, as this paper will show, career paths for women within the large audit firms in Saudi Arabia are fraught with obstacles, many of which are not encountered in the western offices of these firms. The environment within which women operate is male dominated and often they will be working for foreign managers and dealing with foreign clients alongside Saudi nationals. The accounting profession employs significantly more non-Saudi accountants in the Kingdom, compared to Saudi nationals and SOCPA is in the process of "localising the profession" in conjunction with the Ministry of Labour and Social Development. ${ }^{18}$ This is significant because, as the study will show, the firms (and line managers in particular) help the women to negotiate the religious, social and legislative constraints that impinge on their capacity to undertake audit work. Firms have adapted to accommodate the strict requirements for the separation of male and female employees and to meet client demands (see also Agrizzi et al., 2018).

\section{Research Methods}

The main concern of this study was to gain an in-depth understanding of women auditors' perspectives of their working experience in the profession in Saudi Arabia and thereby understand the process of change taking place in the profession. In order to facilitate this, we set out to gather rich contextualised data from in-depth interviews with women auditors working for the large global firms. Whilst access to these accounting firms has traditionally been challenging due to confidentiality concerns (Anderson-Gough et al., 2005) and research access in Saudi Arabia is also difficult (Hodges, 2017), we managed to secure authorisation for a significant number of interviews with staff from the Big 4 audit firms based in Saudi Arabia (located in Riyadh, Jeddah and Al-khobar). ${ }^{19}$ In total, we interviewed 42 accountants (28

\footnotetext{
${ }^{18}$ The Secretary-General of SOCPA stated: "the total number of Saudis working in the field of accounting does not exceed 4,800, compared with 167,000 non-Saudi accountants" (Source: https://www.argaam.com/ar/article/articledetail/id/533889; 7 March 2018).

19 In order to practice, an auditor must be registered at the Ministry of Commerce and be a Saudi national. The large accounting firms often have agreements with local firms, thus KPMG is not officially a Saudi legal entity but operate through Alfozan through licensing and servicing agreements. A review of the company accounts of the largest Saudi companies shows that the audit reports are signed off by the Big 4: Saudi Basic Industries Corporation (Ernst \& Young); Saudi Telecom Company (Ernst \& Young); Al Rajhi Banking \& Investment Corporation (Joint KPMG Al Fozan \& Partners Certified Public Accountants and PricewaterhouseCoopers);
} 
female and 14 male - denoted by $F$ and $M$ respectively in the descriptors) and additionally held informal and formal conversations with policy makers at the Ministry of Labour and SOCPA (See Appendix A). Although there were 42 participants in total and a large amount of data was gathered and analysed for this project, only illustrative quotations that are relevant to the themes selected for this paper are presented as evidence. Often participants would make similar points and in the analysis phase we had a variety of quotations on the same topic at our disposal and made judgements about which to present.

Purposive sampling was employed to select women for interviews, starting initially with personal contacts. The majority of our interviewees were female and single, as cultural norms dictate that women often stop work after marriage. We were surprised to note that, although childcare issues are a key concern for many working women in the West, in our study this was not the case for the married Saudi women auditors we interviewed: Because here she can wake up and leave her child with the Nanny or her mother or mother in-law, then the driver will take her to work (F18). We believe that an important contribution of this study is the fact that the interviews were conducted by a female Saudi national, who is a qualified accountant, a SOCPA member and has worked within the auditing profession in the country. This is significant for a number of reasons. Firstly, she was able to draw on professional networks with previous colleagues. Secondly, at a practical level, the interviewer had a pre-existing understanding of the gender norms that she would need to accommodate, as noted in her diary:

Then F4 (Female participant 4) came in, she was covering her head, her face and all her body, except her eyes. I asked her if she [would] prefer to do the interview in the meeting room (in the male section) or in the female section, and she chose to do it in the female section. We went together to the female section which was in the same building but within distance from the male section and has a completely separated space and entrance. The door of the female section has a password and could only be opened by an electronic card for authorized people only. When we arrived at the female section, she took off her head cover and her Abaya.

Finally, when making decisions regarding method, analyses and interpretation of the data, that pre-existing understanding came into play and was revised and re-examined in "the light of new understandings" (Haynes, 2008). For instance, based on the interviewer's own experience the

National Commercial Bank (KPMG Al Fozan \& Partners and Ernst \& Young); National Commercial Bank (Joint KPMG Al Fozan \& Partners and Ernst \& Young). Similarly the audit reports of state-owned companies such as Maaden and Saudi Aramco are signed by PricewaterhouseCoopers. 
themes of the interviews were initially structured around issues of career opportunities and constraints, but as the study fieldwork progressed it became evident that issues of identity construction were also strong themes in this study. In interview-based research, forms of identity such as gender, age, language and ethnicity can impact directly upon the relationships formed, the data gathered in interviews and, ultimately, its analysis. The commonalities shared between the interviewer and the female interviewees in this study adds a degree of contextual validity and, we feel, provides for a richer understanding of the complex experiences under study. The interviewer believed that her shared experience enabled female interviewees to "confide in her".

Male participants were interviewed in addition to female participants, recognising that male and female professionals experience their firms differently and to gain an understanding of the complex and often paradoxical gender relations in organizations (see also Anderson-Gough et al., 2005; Gammie and Gammie, 2007; Dambrin and Lambert, 2008; Lupu, 2012). In the Big 4 audit firms in Saudi Arabia, women work within a predominantly male environment and although many Saudi men welcome the opportunity for women to contribute to the labour market, others fear change. In selecting the male interviewees, the interviewer utilised connections with friends, relatives or colleagues who worked in different accounting firms to identify willing male participants. The main reason for adopting this strategy with the male participants was because full segregation of male and female workers exists in Saudi Arabia. Therefore, accessing male participants in the work place was expected to be difficult because the interviewer was a Saudi female and some degree of trust or personal connection or recommendation was required to initiate contact. We believe that surmounting these practical difficulties in order to facilitate the inclusion of male participants helped us to achieve a more holistic view of the women's environments and experiences. And in doing so, we were able to capture not only the views of males that supported women working in the country but also males that did not.

In-depth interviews were conducted using both open-ended and semi-structured questions and each lasted between forty-five to sixty minutes. A pilot study had been conducted and this, along with themes identified in the extant literature, informed the construction of interview questions. Some interviews were conducted in English since many of the participants were fluent and others in Arabic. All were recorded with the participants' permission. Notes were also taken of the researcher's observations of the women at work and information in official 
documents. The data collected was analysed qualitatively, using thematic analysis as the primary analytic approach. Initially the analysis involved careful reading of the transcripts while listening to the recordings and highlighting the main issues as they related to the research objectives. Codes were then generated from the data and organised into themes and sub-themes. Ongoing analysis was performed to improve the process, generating clear definitions and names for each theme (Alsalloom, 2015). In this phase, the data analysis was organised and coded using NVivo. Continuing reflection on this process and reduction and refinement of the data resulted in the derivation of four clear themes for this particular study: guardianship and family honour; mobility restrictions; dress codes (and identity); and negotiating the professional client relationship.

\section{Negotiating gendered constraints for female auditors in Saudi Arabia}

In this section, we present the data gathered from interviews with pioneering Saudi women who have embarked upon careers in audit with the big international firms. We focus on four specific areas that Saudi women auditors must negotiate within their everyday work environment: guardianship and family honour; mobility; professional dress codes and client access. We show how the particular religious and social expectations of Saudi society act to hinder the capacity of the women to perform their jobs effectively. We highlight gender inequality and the effect on career progression of denying women opportunities that are available to equally qualified men. Furthermore, we also touch upon the strategies adopted by the women themselves, as well as their firms, to manage and overcome gendered constraints.

\subsection{Guardianship and family honour}

The family plays a significant role in the lives of the women that we interviewed. In this part of the study, our aim was twofold: firstly, to ascertain how family honour and guardianship rules (and the resulting requirements for physical segregation) impinge upon the daily experiences of our participant women auditors and how these are navigated; and secondly, to examine how the firms try to help their employees to negotiate the constraints they face.

Family support is essential in order for a woman to enter the profession and take a position within an audit firm. Our findings suggest that all of the accounting firms supporting this study, were very much aware of and concerned with family support for their female auditors. Our 
interviewees relayed their own experiences of employment interviews, in which it was perfectly acceptable to ask about the woman's personal relationships and standing, something that would not generally be accepted, or indeed comply with equality legislation, in many western countries:

"When I was employed here I was not married, so one of the questions I had at the interview was, 'Suppose that your husband doesn't want you working'. I said, 'No I will give him the idea that I am going to work.' So he [the interviewer] said, 'Ok, but suppose that he changes his mind when he sees the situation.' I said, 'I will try to balance it; I will not make him hold anything against me which can make him say this is because of your job, leave your job'."(F/4: Female Senior Audit Associate, Firm 1)

This quote shows how the interviewee was keen to emphasise her commitment to work and how she had to respond to a hypothetical question about her future plans for marriage. The interviewee has to show in her answer that she will balance her desire to work with social expectations that view a woman as a wife and a mother who needs permission from her husband/family to work and needs to be protected by her husband and male family members. The deep-seated concerns over a woman's reputation and honour spread far beyond her own immediate family and impact on her role in a professional accounting environment. In one encounter, a Saudi male interviewee's comments provide some insight into how they feel social pressure to "protect" their female colleagues and in some sense to adopt the guardianship role on behalf of her family.

"For example, a lady said that if she wants to go for a job outside the office, like to audit the client's financials, she goes from the office with her work colleagues. So I said, 'Wait please, you go with your male colleagues! Does your family know about this? Your family have left you here in our care'." (M/27: Regional CEO, Firm 1)

The firms are alert to and bound by the guardianship rules, acknowledged here by the CEO who understands that women are left "in our care". Thus, the guardianship role is transferred from male members of the family to men in the company when the woman is entrusted into its care. Perhaps uniquely in the profession in Saudi Arabia, the recruitment process not only focuses on qualifications and suitability for the role, but also on the match between the employer, the female applicant and the expectations of their family - that is to say that only 
those with evident family support and an understanding of the nature of audit work will be recruited:

"We do anticipate and try to explore with them [female applicants] their flexibility.... So we do explain to them that they should expect to be at the clients and how the work environment is. How flexible they are to that, can they adjust, are they comfortable? Some of them have families who do really have a desire to know where their daughter is going to be from 8:30 to 5.00, so it's very important that they are fully aware of it ... some actually get a bit surprised, ... and some of them come back and say that we have these issues and we are not comfortable to continue, so they will withdraw." (M/15: Partner \& Head of Audit, Firm 4).

Consequently, women are generally perceived by employers as higher employment risk than their male counterparts, particularly in occupations such as auditing, which require interaction with the opposite gender, flexibility in working hours and travel.

Although a woman's right to work is guaranteed by law in the Kingdom, subject to family agreement as outlined above, these same regulations require the segregation of men and women in the workplace. This is regulated by the Ministry of Labour, influenced by the requirement to maintain family honour: "a woman should work in a private place and be separated from the men's workplace, simply she cannot work with men." (M/32: Government Official in the Ministry of Labour). In practice, this means that the firms arrange for the creation of a section completely separated from the male work area, in which women have their own facilities, ideally closed off by a door with private access. ${ }^{20}$ In an international audit firm, the potential for 'mixing with males' is obviously increased as audit teams are sent out to client premises. This situation raises unique issues not encountered elsewhere: "... as a woman working as an external auditor ... I am working with men, which is not very accepted in Saudi Arabia." (F/31: Audit Trainee in Firm 4). The pressure to avoid male contact coupled with the need to "please the families" can result in the 'ghettoization' of women in lower-paid work or less prestigious areas within audit firms. We develop this line of thought further in the following sections. We turn now to the issue of mobility and how this affects the ability of women auditors to negotiate everyday work requirements.

\footnotetext{
${ }^{20}$ Women-only spaces are required both at the firm's office and at the client's premises. See also Agrizzi et al., 2018 .
} 


\subsection{Mobility restrictions}

A key barrier to increasing female labour participation rates in Saudi Arabia has been mobility restrictions due to the driving ban imposed on women on the advice of religious clerics and the lack of access to alternatives such as public transport (Baki, 2004). Under the guardianship rules, a working Saudi woman is entirely dependent on either her male guardian or taxis to be able to move around. Auditors are required to travel to the premises of the client to conduct investigations, which has created another layer of near-impossible constraints for professional women. There has been much debate over the driving ban and following public protests by Saudi women $^{21}$ a prohibition fatwa was issued in 1991 (Al-Rasheed 2013). The state responded harshly to the protests as they highlighted tensions between those wanting a more liberal, evolutionary Islam and the state's interpretation of Islam drawing on its Wahhabi heritage (Doumato, 1992, p.3). However, in September 2017 Saudi Arabia announced that it would allow women to drive from June 2018 (BBC News 27 September, 2017). Despite this new ruling, the general feeling seems to be that the ban is so deeply engrained within Saudi society that it may be some time before it is fully accepted (Elamin \& Omair, 2010). The present study was conducted when the driving ban was still in force and our contacts have since suggested that things are not that different.

Our data shows that female auditors' capacity to undertake client visits, which are inherent to audit work, is severely restricted. Some women have a family driver that they can use to drive them to audit clients but, for those that do not, firms do provide a transportation payment allowance. Even so, our interviewees expressed frustration with the mobility issues they face daily:

"... guys can visit two or three clients in one day while we cannot! They can freely move from one client to another in one day, while for us the transportation restriction is an issue. I have my own [family] transportation, but it is not available for me 24/7. So, I don't know when I will be finishing with one client to be able to move to another. I can't keep the family's driver waiting..." (F34: Audit Associate, Firm 1).

\footnotetext{
${ }^{21}$ For instance, on the $6^{\text {th }}$ of November, 1990, a group of Saudi Arabian women protested against the driving ban. They were taken away by the religious police and were released only after having their male guardians signing pledges (Al-Dosari 2016; Hubbard 2017). At that time, posters appeared in public places stating that "'here are the names of the sluts who advocate vice and corruption on Earth" (Doumato 1992). King Fahd subsequently issued a decree suspending the protesters who had government jobs and preachers condemned them during Friday prayers.
} 
The issue is exacerbated as alternative forms of transport are also restrictive. Buses are not always practical for reaching clients and women are required to enter by a separate entrance located in the back and have designated seating (Baki, 2004; Jerichow, 1998). In fact, some of the largest bus companies in the major cities do not allow women at all. Taxis can be an option but many of our interviewees regarded them as unreliable and unsafe. Therefore, in the absence of freedom of movement, women auditors forgo opportunities to develop their experience in diverse settings, which, of course, has implications for career progression. Our interviewees told us that women auditors need to schedule their transportation in advance, particularly those in senior roles, who have more out-of-office responsibilities to attend to. It was clear that the issue of daily mobility creates problems for women, since they need to manage time and cost alongside societal pressures:

"I cannot visit clients with my team, because my team are guys. I cannot just grab a taxi myself, because I fear to do so, since taxis here are not safe. I don't have my own car, while a male colleague can just jump into his own car and drive off. The company does not provide us with a car. Therefore, my option is to book a private taxi, which becomes a financial burden." (F13: Senior Audit Associate, Firm 2).

The firms are aware of such issues and have considered various options, including provision of chauffeurs, but this was not regarded as feasible by one senior manager:

"We thought of providing women with a car and a chauffeur. But is this not feasible to have a chauffeur for each woman every time they need to visit a client. However, we understand that women cannot visit two clients in the same day, while we expect men to do. But, this transportation issue may deprive women from getting more engaged - i.e. sometimes they cannot attend meetings with clients, because they may not be there on time..." (M28: Audit Executive Manager, Firm 1).

This raises another issue of inequality, because women from wealthier families will have access to chauffeured transportation whereas those from less wealthy families tend not to be given outof-office assignments and auditing jobs due to lack of transportation. Position in hierarchies of wealth - or class - are therefore a differentiating factor in Saudi women's experience, also noted in Syed et al's (2018) study which highlighted the interaction of class and gender in the Saudi context. In addition, women who do not have permission from their families to travel will not be assigned to jobs further afield, for instance assignments requiring air travel, as firms would wish to avoid being embroiled in disputes with families. Therefore, issues relating to mobility have a 
significant impact on the kinds of work women auditors can do, their professional experience and, ultimately, career progression. When women auditors do manage to reach the clients' offices, they are required to negotiate yet another set of hurdles, to which we now turn.

\subsection{Accommodating dress codes}

Much has been written about the strict dress codes for women in some Islamic states. ${ }^{22}$ For instance, Kamla (2012) examines the specific circumstances of marginalization and exclusion that Muslim women in accountancy can face in a changing global context, in particular in relation to choices made regarding wearing the hijab. She notes that in Syria the government actively sought to discourage the practice of wearing the hijab (throughout the 1980's and 90's) as part of its long-standing struggle with the Islamists (p.189) and therefore women wear the hijab through active choice. ${ }^{23}$ This is different to the situation in Saudi Arabia where, in spite of recent statements made by the King, strict dress codes still apply.

In the workplace, interviewees experienced conflict between balancing religious and cultural values related to dress with job requirements. The conflict arises because the international firms employ large numbers of foreign professionals alongside Saudi nationals and encourage the portrayal of an essentially western image. However, in Saudi Arabia this image is at odds with the local requirements for modest dress for women in accordance with religious and cultural norms. For this female accountant, an expectation that she remove her veil meant that she did not take up a job:

"I applied once to a company and the manager was happy with me and my qualifications, but when he saw me he said 'you have to remove your veil to work here'. I said 'no, sorry, I can't. I have worked for a long time and I didn't remove my veil, what's the difference from seeing my face or not, I am doing my job!'. Then he said: 'to see your facial expression.' So I said: 'but you can see my eyes and the eyes are enough

\footnotetext{
${ }^{22}$ Metcalfe (2007) argues that the hijab (or veiling) constitutes an important part of women's professional and social identity; suggesting that one cannot understand the complexity of gender without connecting the social broader and economic changes relating to women's rights in Islamic nations. Kamla (2012) notes that Muslim women maintain that the hijab is a 'symbol' of solidarity and in some contexts has become a 'symbol of anticolonial resistance' (p.191). Others suggest that they see veiling not only as a religiously legitimate practise, but also a symbol of identity and a means of extending their cultural and socio-political spheres (Ahmed, 2011; Karam, 1998).

${ }^{23}$ Also see Kamla, 2012 (p191-192) on the resurrection of the hijab throughout the Arab world in the latter part of the twentieth century and for a discussion of what the "new veil" says about the woman wearing it.
} 
to give you an expression'. I didn't take that job." (F/30: Accountant, now a lecturer at King Abdul-Aziz University).

The issue of women's dress is brought into sharp focus in relation to relationships with clients, as the role of the auditor involves close contact and communication with fee-paying clients, who exercise power in the auditor-client relationship and whose requests hold gravity. Our participants described many situations in which clients specifically requested that the female auditors consider their dress, and in particular the veil:

"Some female trainees had some issues with the niqāb. Some clients did not want them to wear it and asked them to remove it, which I don't think is something reasonable to ask." (F29: Tax Consultant, Firm 2).

However, women encountered both clients who did not view religious dress as appropriate to the professional environment as well as those who objected when female auditors were seen as "not complying" with strict Islamic law. One of our male participants commented:

"There are two kinds of people [clients], one who says if I get a woman who is committed and decent I will not mind, but if I get a woman who is not dressing in a decent way and sits with men like this [unveiled], no I don't want to support this kind of practice." (M/33: Accountant, SOCPA Representative).

In these circumstances, women auditors struggle daily with the contradictions - while they need to dress respectably, both from a social and a religious viewpoint, they also need to present what is deemed to be a professional image within the context of Saudi Arabia. Some interviewees were not fully veiled, but still noted the importance of suitable dress:

"No. I don't cover my face, I only wear the hijab. ... The most important thing is that I need to be presentable, my Abaya is a good Abaya, and my shoes are good shoes because in the end I am going to clients I need to present a good example of my family, my job, and my company ... these clients always take the first impression, so you need to be presentable to represent the firm." (F/17: Audit Associate, Firm 4).

In addition to negotiating the moral hazards associated with dress, there are also physical considerations. For instance, in some working environments the female and male sections are not completely segregated, so in these cases our participants told us that: "I am wearing my 
Abaya and Niqab all the time ... he can come to my office any time" (F/16: Tax consultant, Firm 4). However, where there are women-only areas it is possible to remove some elements of outer clothing purely for comfort:

"In our section I usually wear an Abaya and a scarf, although sometimes we remove our head scarf ... but, if someone knocks or we go outside, we wear our scarf again"' (F/17: Audit Associate, Firm 4).

The physical restrictions associated with wearing long flowing dress also have implications for the kinds of jobs the women auditors can be assigned to, for example in industrial sites:

"Inventory counting needs physical movement from you. It depends on the client's company. For example, if you go to an industrial corporation to count a container you need to go up a track, so I don't think you can do it with the abaya. Not only that, also because of society and culture, you need to bend to count things and so that 's difficult." (F/18: Audit Supervisor, Firm 2).

In this setting, dress codes represent a combination of symbolic aspects of the professional identity of auditors, of personal self-expression and of conformity with social and religious norms of modesty and respectability. While dress is a concern of professional women in most contexts, particularly when operating in male-dominated arenas, the social norms derived from religious interpretations of dress codes in this case provide a further dimension to women's choices, as well as to the accepted dress codes (formal or implied) of the corporate world. We see women making individual decisions about their own dress, which may change according to context, that balance the expectations of Western norms of business dress with Islamic dress rules.

\subsection{Negotiating the client relationship}

The literature notes that client expectations and demands, whether expressed or implied, dictate gendered practices in audit firms (Anderson-Gough et al., 2005). International accounting firms pursue client-focused strategies for obvious economic reasons, but such an approach does not easily accommodate the peculiarities of the case of women auditors in Saudi Arabia, where the very notion of women working remains unacceptable to many sectors of society. In this section, we examine the experiences of the women auditors as they engage with clients and, specifically, draw attention to strategies adopted by the firms with respect to managing the 
client relationship, in order that women auditors receive the required breadth and depth of experience. We observe that firms manage sensitive gender relations by 'working around the restrictions'.

\section{Temporal commitments}

The predominantly Western gender and accounting literature has highlighted the long working hours required of auditors as an issue for women with family commitments. In the case of Saudi Arabia, notions of guardianship and family honour mean that working hours are an issue for women generally as most families will not permit late hours for either single women or those with family commitments. To accommodate this, some firms offer women auditors fixed hours:

"Our working day is to 6pm, sometimes we stay longer but honestly not as long as men do, because they let us go early, I mean still there are exceptions... they take us into account." (F/9: Audit Supervisor, Firm 2).

While the strategy of fixed hours helps the firm to "work around" the constraints and is positive in enabling women to participate in the first place, it can also have negative consequences. For instance, the commitment required to complete a job on time may not coincide with the fixed hours and our interviewees told us that they are sometimes prevented from seeing allocated audit tasks through to completion - although this was not always seen as problematic by male managers:

"With females they are always careful to treat them well, and this keeps the female happy to work here. I see it, sometimes in the season the male auditors stay until 2 am or to sleep over in the office, but females go early, for example, if there is a deadline they will not sleep in the office to finalise it. Maybe they finish at home, maybe they even don't, like they are not under pressure, they are not in front of the gun." (M/14: Audit Manager, Firm 2).

However, as with other aspects of women's working lives, the issue of hours is also subject to contradictions; some interviewees testified that even if they wanted to stay after hours to complete work there could be consequences:

"For women in banks, 5.00 or 5:30 is the end of their regular working hours and women are not allowed to stay later. One time I had to stay late at a banking sector client and 
the security guy asked me why I am staying late. Of course, if the banks' female employees stay late they will violate the system and it will be reported on their file." (F/4: Senior Audit Associate, Firm 1).

Although Saudi Arabia has now officially loosened the guardianship rules (and further announcement were made on 2 August 2019), it remains the case that in a range of activities and life choices Saudi women still cannot decide for themselves. Thus, our Saudi-based coauthor commented that "if the women stayed late at work at this particular banking client there would not be an official punishment but such violations would be noted in the woman's file held in Human Resources". Some families would not tolerate late working and force their daughters/wives to leave work rather than besmirch family honour by allowing them home late.

\section{The allocation of work}

In most audit offices, jobs are allocated on the need for particular experience for a trainee, or their availability, or specialist expertise or even geographical proximity. In our study, we found that the (usually male) audit managers are required to balance the need to ensure adequate experience for their female employees with the circumstances of their clients. Women auditors can only be sent to clients that comply with the Ministry of Labour directives on segregation and provide female-only sections, thus the client's working environment is a key consideration in the allocation of audit work:

"I refuse to send women auditors working under my supervision, to client firms that don't have a female section. ... for example, if she needs a place to pray or so ... it's difficult to stay for nine hours, also it's embarrassing for her. I don't want to send her to a place where there are no females and she will be the only woman ..." (M/28: Audit Executive Manager, Firm 1).

As a means of circumventing or accommodating the strict religious requirements and social constraints placed upon women auditors, senior staff in audit firms exercise a degree of sensitivity when it comes to the allocation of audit jobs and planning staff workloads:

"We have to be mindful of our client's ability to accommodate females and what is the work environment. This is important, so we bear that in mind, when we do the analysis to ensure where women can be utilised in their career or in the next 12 to 18 months, which clients they 
can go to, how much time they will be utilised ... because also if they (the women) have very low utilisation they will not be satisfied." (M/15: Partner \& Head of Audit).

The allocation of audit work and interaction with clients is further complicated by the fact that some clients in Saudi Arabia refuse to accept women auditors per se, as this participant recounts: "Some clients have a sexist view of women, as 'I don't want to see women here', sometimes a client says 'don't send women to me'." (M/19). In some instances clients are initially resistant to making accommodation for women auditors, but some do so in time:

"I had a problem with one of my clients, I was supposed to go to them and audit them, and then when I was on my way they called my senior and said 'no, we are sorry we don't let females in', so I had to wait like a whole week until they made a place and a room for me so I can sit there ... yes, I went, they just had to make sure that I had my own little space." (F/35: Audit Associate, Firm 3).

Audit managers indicated that it was often easier to allocate women to clients with a predominantly female workforce that already employed women in senior roles, or were known to have female-only sections. Mostly the managers are men who need to determine which clients are a feasible prospect or will assist in complying with their guardianship responsibilities in loco parentis. This can mean a preference for certain sectors:

"I would say certain sectors you will find that there is a better work environment or a work environment that allows women, such as financial sector. In general most of the banks have female sections and flexibility in their work environment, so when females go there they are not sort of unique or alone. I mean it's just to give them comfort because these companies are more prepared." (M/15: Partner \& Head of Audit, Firm $4)$.

\section{Gaining experience and progression}

Women professionals in Saudi Arabia face a very different set of barriers to progression to higher levels than those encountered by women in other parts of the world. The sections above have shown that attitudes to women's participation in the workforce and rules about gender segregation at work, mean that women auditors experience limitations in gaining experience 
with a range of clients. The effect is that such restrictions ghettoise the women into certain areas of audit and deny them the breadth of experience that is open to male colleagues:

"Some girls can go to a stock count if it's like a chocolate factory or a clothing line or whatever, but industrial areas, no you can't do that ... if it deals with warehouses or big machines or things like that, they will say, no don't go there, it's dangerous for women" (F/35: Audit Associate, Firm 3).

Our interviewees were aware that they would miss out on opportunities to gain wider experience:

"I feel I am missing some experiences. I didn't go to most of the industrial sector, and the petrol and oil companies. As long as these sectors don't employ women I cannot go to them. " (F/21: Audit Associate, Firm 1).

There is some commonality here with Kamla's (2012) findings on the ghettoisation of women in certain jobs in Syria, where almost $68 \%$ of female university graduates work in the public sector, compared to only a quarter of men.

The imposition of segregation rules has led some international audit firms to rethink the audit model in operation, with one response being to concentrate women in the more private sphere of a non-client-facing role such as tax.

"... They don't have to go out of the office, not all women want to go out, ... we need committed people. Tax is excellent for girls, I always say to them go to tax, it's a new field, a new world for girls."(M/28: Audit Executive Manager, Firm 1).

Although this may appear an inclusive strategy to overcome gender constraints, in reality tax may be perceived as holding a less prestigious status within audit firms, therefore it could ultimately legitimise exclusion from the full range of audit roles for most women and limit their opportunities with the profession. Ghettoization in certain types of work can have several consequences: firstly, women do not receive the same breadth of experience as their male counterparts and the limited out-of-office assignments and exclusion of women from certain types of jobs deprives them of opportunities for professional advancement; secondly, the predominantly male workforce is conditioned into believing that women are not suitable for certain kinds of work as they do not see women in a range of positions; thirdly, this normalises 
only some professional routes for women and not others, with consequences for the careers of future women auditors. While the political objective of the government is to open up more opportunities and increase women's participation in the workforce, in practice our evidence bears witness to a potential form of re-segregation of women auditors into "acceptable" (and less profitable) areas.

\section{Organizational efforts to overcome the restrictions}

Audit firms are well aware of this potential for ghettoization and restriction in experience and our interviews revealed that this is being countered in a number of ways. Firstly, the practice of staff rotation ensures that the same individuals are not sent to the same "female-friendly" clients year on year, although this is quite different to many western audit firms that encourage their staff to build relations with clients by attending the same jobs. Secondly, the international firms have a very large client base, which provides greater choice for staff allocation decisions. Finally, the firms have many international clients with non-Saudi employees who they know will be more accepting of women auditors. Positive steps have been taken by some firms to actively support their female auditors:

"We are trying it in this office: we defined those clients who are likely to accept women working with them ... we select clients from different industries. So there could be a rotation from one client to another in order to gain different experience. For us we solved the problem ... because we have a large group of clients." (M/6: Audit Partner, Firm 2).

The allocation of the pioneering Saudi women auditors to larger multinational clients which are more accepting of women is in contrast to the extant literature which suggests that historically pioneer women in the profession were often allocated to the least prestigious jobs (Kirkham and Loft, 1993; McKeen and Richardson, 1998; Walker, 2008).

Despite the attempts to assist women auditors in the negotiation of the constraints placed upon them women by the guardianship, mobility and segregation rules, our findings suggest that the international audit firms remain essentially a male-dominated arena. The firms have introduced certain practices to accommodate women auditors in line with government edicts and policies regarding the inclusion of more women in the workforce. It could be argued that the result is the creation of what might be called a 'feminine version' of audit specific to Saudi Arabia - a 
version in which the needs of the women auditors are given special consideration, which can result in a re-segregation of women into 'safe' areas of the profession. While some firms have introduced practices to overcome the disadvantages associated with limited client experience, the segregation of women into 'female-friendly' areas in the public sector such as health and education, as well as less prestigious areas of work such as taxation, will limit their experience and access to other areas of auditing.

\section{Conclusion}

We have shown how reforms to counter gender inequality in the country are taking place within the confines of religious nationalism adopted by the state which allows religious clerics to have considerable sway over political decision-making. Our study highlights how the rules resulting from a particular form of religious nationalism penetrate the work environment, subjecting female auditors to marginalisation at multiple levels that, when combined, produce an experience that is distinct from other gendered experiences encountered in the accountingrelated literature. Women have only recently been able to train as auditors and accountants in Saudi Arabia, due to political changes aimed at transforming the country from an almost entirely oil-dependent economy to a more diverse industrial and service-based one. Driven by political edicts encouraging female participation in the workforce, the Big 4 international accounting firms have felt obliged to accept and train female auditors, adjusting their own practices in order to accommodate them in the process.

We have presented original evidence of how this pioneering group of women, and their employers, attempt to circumvent some of the barriers encountered. We have shown that women are very aware of the limits placed on their opportunities to work with a range of clients that male colleagues do not encounter, due to mobility, dress and segregation requirements. Yet within these limits, the women adapt in order to balance the competing demands of professionalism, social norms and personal preference. The women auditors we encountered, though, were not a homogenous group, adopting different attitudes towards questions such as dress or working alongside men, depending on personal identification and professional identity, family expectations and indeed class or wealth differences. Thus, one interviewee refused a job due to expectations that she remove the veil, while others showed flexibility over face or head covering according to context. These variations are likely to stem from a more complex set of contextual choices than simply reflecting either liberal or Islamist versions of feminism adopted by Saudi 
women, as identified by Al-Rasheed (2013). As noted in relation to mobility, differences in access to a private driver also affected women's options in relation to access to client premises. Our analysis highlights the importance of paying attention to differences in the women's feminist beliefs, class and wealth differences and personal attitudes to dress in order to understand the experiences of Saudi women auditors.

The paper also explored the role of male managers as guardians to facilitate the participation of women auditors, taking on the protective role accorded to male family members, in what could be considered as a form of 'in loco parentis' guardianship at work. Thus, the study highlights that managers play a significant role in both maintaining limitations and opening up opportunities for women auditors. We found that managers modified their diversity management practices through a more flexible work allocation model, taking into account not only the woman trainee's need for experience, but additionally the clients' willingness to accept her or provide a femaleonly work area. Working around the constraints in this way to allocate jobs appropriately means that the corporate model can accommodate women auditors within the gender constraints applying in Saudi Arabia. However it also means that they are often confined to "womenfriendly" jobs, clients and sectors, perhaps creating a 'feminine version' of audit specific to Saudi Arabia. In this way it could be argued that Western, androgynous versions of feminism that seek equality with men are not applicable, but instead an Islamic feminism that recognises gender complementarity is more appropriate to this context. We have distinguished between 'Muslim feminists' and 'Islamist feminists'. Muslim feminists are more inclined to adopt the discourse of equality between men and women, while Islamist feminists do not seek equality with men but rather value women's difference and dignity as women (Karam, 1998, cited in Franks, 2002). We see, in this, acceptance of a 'feminine version' of audit in Saudi Arabia a recognition of women's professional contribution, but on different terms to men. The difficulty for those advocating gender equality in the profession is that by adapting to Saudi cultural and religious rules, women are denied a breadth of experience that can be necessary for progressing further within the profession

Furthermore, such an outcome may be a form of "within-sector re-segregation", at a time when national policy is ostensibly seeking to de-segregate or at least open up greater opportunities for women in the labour force and in professions to which previously they did not have access. Rather than seeking to deny or reconcile the differences among feminist scholars wanting change in women's position, Franks advocates for issue-based coalitions or "collaboration on social research by communities of shared interest [that] might bring about targeted local change as well 
as influence global attitudes to particular issues" (Franks, 2002, p.45). This could apply to pragmatic strategies for change in auditing firms in Saudi Arabia, that recognise what is possible within the current rules on guardianship, dress codes and gender segregation, while also pushing at the boundaries and taking advantage of shifts in religious, cultural and social norms (for example about driving). The study has valuably shown, for example how male managers view the constraints on women auditors and how they work both within and around these to balance the women and the firms' needs to deploy women with a variety of clients. Furthermore it highlighted the practices of some firms that can support the development of women auditors' careers, such as the rotation of staff to different clients, or deployment with international clients who may be more accepting of women auditors. However, there may be further accommodations that firms could make, for example in relation to the provision of transport to client sites to overcome women's mobility restrictions.

It is important to note that the consequences of the particular interplay of gender, politics and religion observed here are not universally applicable to Islamic contexts. Saudi Arabia adopts a particular interpretation of Islam that does not apply in other Islamic settings, for example the mobility constraints discussed here, particularly in relation to driving, are unknown elsewhere. Similarly, the application of Islamic dress codes is highly variable across national settings and takes a specific forms in Saudi Arabia. Equally, the guardianship rules apply in particular ways in Saudi Arabia, although some underlying principles may be observable in other countries. Thus, we can say that political choices interact with the application of Wahhabi principles to produce a particular gendered experience for Saudi women auditors. The direct outcome is a professional experience that offers far more limited opportunities than those available to their male counterparts and that of other women auditors in the same firms elsewhere.

This paper has not been able to address, in depth, the aspect of class-based and wealth-based differences in women's experience. For instance, those that have drivers and can easily transfer between clients and those that do not, highlighted by other studies as significant (Syed et al, 2018). This certainly would be worthy of further academic study. Further research could additionally consider differences in access to 'wasta' or networks that restrict/afford women's access to professional or leadership positions (Hodges 2017). This study was also not able to pursue the extent to which women may act to challenge or resist the gendered obstacles that they 
face. As women continue to enter the profession in greater numbers, it is possible that further changes to their working environment will be called for by the women and responded to by their employers. It will also be interesting to examine the effects of the recent political edicts encouraging the participation of women, together with actions to meet the 2030 target, on the progression of women in the profession. Additionally, some male participants indicated that work allocation was "unfair" because of the special treatment afforded to women, thus further research on the reactions and views of male colleagues to the entry of women to the accounting profession would be valuable.

Our study shows that whilst state reforms and intervention have helped women to gain entry to the big accounting firms in Saudi Arabia, their experiences therein remain strongly shaped by the intertwined forces of religious nationalism and cultural and social norms. On a more macro level, it has been suggested that even with full Saudiization, it is unlikely that there would be enough jobs for Saudi men and women. Therefore it may be in the political interests of the Saudi regime to side with ulama and perpetuate sex-segregation and the underemployment of women in order to claim that they are maintaining and safeguarding the higher moral values of religious nationalism, rather than admitting failure in attempts to create more jobs locally for both men and women and improving the economy (Doumato, 1999). The tension between religious nationalism and modernisation remains strong. However, given the diversity policies adopted by the big accounting firms internationally, the recent changes to Guardianship Laws and the views voiced by the pioneering women in our study, we suggest that the door that is now ajar to women auditors in Saudi Arabia will open further in the foreseeable future. 


\section{Appendix A: Participants}

\begin{tabular}{|c|c|c|c|c|c|}
\hline Gender/Participant & Position & Organization & $\begin{array}{c}\text { Marital } \\
\text { status }\end{array}$ & $\begin{array}{c}\text { Children } \\
\text { Yes/No }\end{array}$ & Nationality \\
\hline $\mathrm{F} / 9$ & Audit Supervisor & Big-2 & Married & Yes & Saudi \\
\hline $\mathrm{F} / 11$ & Audit Supervisor & Big-3 & Single & No & Saudi \\
\hline $\mathrm{F} / 18$ & Audit Supervisor & Big-2 & Married & Yes & Egyptian \\
\hline $\mathrm{F} / 4$ & Senior Audit Associate & Big-1 & Married & No & Saudi \\
\hline $\mathrm{F} / 10$ & Senior Audit Associate & Big-2 & Single & No & Saudi \\
\hline $\mathrm{F} / 13$ & Senior Audit Associate & Big-2 & Married & No & Lebanese \\
\hline $\mathrm{F} / 26$ & Senior Audit Associate & Big-1 & Married & No & Saudi \\
\hline F/17 & Audit Associate & Big-4 & Single & No & Saudi \\
\hline $\mathrm{F} / 20$ & Audit Associate & Big-1 & Single & No & Saudi \\
\hline $\mathrm{F} / 21$ & Audit Associate & Big-1 & Single & No & Saudi \\
\hline $\mathrm{F} / 34$ & Audit Associate & Big-1 & Single & No & Saudi \\
\hline $\mathrm{F} / 35$ & Audit Associate & Big-3 & Single & No & Saudi \\
\hline $\mathrm{F} / 8$ & Tax consultant & Big-1 & Single & No & Saudi \\
\hline F/16 & Tax consultant & Big-4 & Single & No & Saudi \\
\hline$F / 23$ & Tax consultant & Big-3 & Single & No & Saudi \\
\hline $\mathrm{F} / 24$ & Tax consultant & Big-1 & Single & No & Saudi \\
\hline$F / 29$ & Tax consultant & Big-2 & Married & No & Saudi \\
\hline $\mathrm{F} / 41$ & IT in advisory & Big-4 & Single & No & Saudi \\
\hline $\mathrm{F} / 31$ & Trainee & Big-4 & Single & No & Saudi \\
\hline $\mathrm{F} / 42$ & Trainee $1+2$ & Big-4 & Single & No & Saudi \\
\hline $\mathrm{F} / 7$ & Trainee $1+2+3+4$ & Big-2 & Single & No & Saudi \\
\hline $\mathrm{F} / 22$ & HR officer & Big-3 & Single & No & Saudi \\
\hline $\mathrm{F} / 40$ & HR officer & Big-4 & Single & No & Saudi \\
\hline$F / 2$ & Partner & $\begin{array}{l}\text { Family-owned } \\
\text { accounting firm }\end{array}$ & Single & No & Saudi \\
\hline $\mathrm{F} / 1$ & $\begin{array}{l}\text { Manager of Financial } \\
\text { and Administrative } \\
\text { Affairs }\end{array}$ & $\begin{array}{l}\text { Local } \\
\text { accounting firm }\end{array}$ & Single & No & Saudi \\
\hline $\mathrm{F} / 37$ & Lecturer & $\begin{array}{l}\text { King Saud } \\
\text { University }\end{array}$ & Married & Yes & Saudi \\
\hline F/30 Lecturer & Lecturer & $\begin{array}{l}\text { King Abdul- } \\
\text { Aziz University }\end{array}$ & Married & Yes & Saudi \\
\hline F/3 Lecturer & Lecturer & $\begin{array}{l}\text { Princess Nora } \\
\text { University }\end{array}$ & Married & Yes & Saudi \\
\hline
\end{tabular}




\begin{tabular}{|c|c|c|c|c|c|}
\hline Male interviewees & & & & $\begin{array}{l}\text { Saudi } \\
\text { national } \\
\text { Yes/No }\end{array}$ & $\begin{array}{l}\text { Muslim } \\
\text { Yes/No }\end{array}$ \\
\hline $\mathrm{M} / 6$ & Audit Partner & Big-2 & Married & No & Yes \\
\hline $\mathrm{M} / 15$ & $\begin{array}{l}\text { Partner \& Head of } \\
\text { Audit }\end{array}$ & Big-4 & Married & & \\
\hline $\mathrm{M} / 25$ & $\begin{array}{l}\text { Office Managing } \\
\text { Partner }\end{array}$ & Big-1 & Married & Yes & Yes \\
\hline $\mathrm{M} / 27$ & $\begin{array}{l}\text { Chairman \& CEO } \\
\text { MENA Region }\end{array}$ & Big-1 & Married & Yes & Yes \\
\hline $\mathrm{M} / 28$ & $\begin{array}{l}\text { Audit Executive } \\
\text { Manager }\end{array}$ & Big-1 & Married & No & Yes \\
\hline $\mathrm{M} / 36$ & $\begin{array}{l}\text { Audit Executive } \\
\text { Manager }\end{array}$ & Big-1 & Married & No & Unknown \\
\hline $\mathrm{M} / 5$ & Audit manager & Big-2 & Single & Yes & Yes \\
\hline $\mathrm{M} / 14$ & Audit manager & Big-2 & Single & Yes & Yes \\
\hline $\mathrm{M} / 12$ & Audit Associate & Big-3 & Single & Yes & Yes \\
\hline $\mathrm{M} / 19$ & Senior Audit Associate & Big-2 & Single & Yes & Yes \\
\hline $\mathrm{M} / 32$ & $\begin{array}{l}\text { Government Official in } \\
\text { the Ministry of Labour }\end{array}$ & $\begin{array}{l}\text { Ministry of } \\
\text { Labour }\end{array}$ & Married & Yes & Yes \\
\hline $\mathrm{M} / 33$ & $\begin{array}{l}\text { A representative of } \\
\text { SOCPA }\end{array}$ & SOCPA & Married & Yes & Yes \\
\hline $\mathrm{M} / 38$ & HR Manager & $\begin{array}{l}\text { Local } \\
\text { Accounting } \\
\text { Firm }\end{array}$ & Married & Yes & Yes \\
\hline
\end{tabular}




\section{References}

Abdulrahman A.M, Al-Twaijry,A.A.M., Brierley,J.A. Gwilliam, D.R. (2003). The development of internal audit in Saudi Arabia: An institutional theory perspective. Critical Perspectives on Accounting, 14(5), 507-531

Abu-Lughod, L. (2013). Do Muslim Women Need Saving? Cambridge, Massachusetts, Harvard University Press.

Adapa, S., J. Rindfleish, and Sheridan, A. (2016). 'Doing gender' in a regional context: Explaining women's absence from senior roles in regional accounting firms in Australia. Critical Perspectives on Accounting 35:100-110.

Agrizzi D., Soobaroyen T. and Alsalloom A. (2018). Spatiality and accounting: The case of female segregation in audit firms. Unpublished conference paper, presented at IPA, Edinburgh, July 2018.

Ahmed, L. (2011). A Quiet Revolution: The Veil's Resurgence, From the Middle East to America. New Haven and London: Yale University Press.

Al-Dosari, H. (2016). Saudi Arabia's Virtual Quest for Citizenship and Identity. Beyond Islamists \& Autocrats, The Washington Institute for Near East Policy.

Alharbi, R. (2015). Guardianship Law in Saudi Arabia and Its Effects on Women's Rights. Unpublished working paper. https://www.researchgate.net/publication/318458165

Al Alhareth, Y., Al Alhareth,Y. and Al Dighrir, I. (2015). Review of Women and Society in Saudi Arabia American Journal of Educational Research 3 (2), 121-125.

Al Lily, A. E. (2011). On line and under veil: Technology-facilitated communication and Saudi female experience within academia. Technology in Society 33 (1), 119-127.

Al Munajjed, M. (2006). Saudi women speak: 24 remarkable women tell their success stories. Arab Institute for Research and Publishing. p. 25.

Al Munajjed, M. (2010). Women's Employment in Saudi Arabia: A Major Challenge. Ideation Center Insight, Booz \& Company Inc (AmCham \& BIAC).

Al-Rasheed, M. 2013. A Most Masculine State: Gender, Politics and Religion in Saudi Arabia: Cambridge University Press.

Al Rawaf, H. S. and Simmons, C. (1991). The Education of Women in Saudi Arabia. Comparative Education, 27(3), 287-295.

Alsalloom, A.Y. (2015). The Role of Women Accountants and the Implications for the Accounting Profession in Saudi Arabia. Unpublished PhD Thesis submitted to the University of Southampton, United Kingdom.

Altorki, S. (2000), "The concept and practice of citizenship in Saudi Arabia", in Joseph, S. (Ed.), Gender and Citizenship in the Middle East, Syracuse University Press, Syracuse, pp. 215-236.

Al-Twaijry, A.A.M., Brierley, J.A. Gwilliam, D.R. (2004). An examination of the relationship between internal and external audit in the Saudi Arabian corporate sector. Managerial Auditing Journal, 19(7), 929-944.

Anderson-Gough, F., Grey, C. \& Robson, K. (2005). Helping them to forget...: the organizational embedding of gender relations in public audit firms. Accounting, Organizations and Society, 30(5), 469-490.

Arebi, S. (1994). Women and words in Saudi Arabia: The politics of literary discourse. Columbia University Press.

Arab News, (2010). 'Saudi woman awarded CPA license.' available online at http://www.arabnews.com/node/346077?quicktabs_stat2=1

Badran, M. (2005) Between Secular and Islamic Feminism/s. Reflections on the Middle East and Beyond. Journal of Middle East Women's Studies, 1:1, 6-28. 
Baeshen, F. (2017). How Economic Reform Will Help Women Drive in Saudi Arabia. Time. Middle East, June, $19^{\text {th }}$.

Baki, R. (2004) Gender-segregated education in Saudi Arabia: Its impact on social norms and the Saudi Labour Market. Education Policy Analysis Archive, 12(28), 1-12.

Barker, P. C., and Monks, K. (1998). Irish women accountants and career progression: a research note. Accounting, Organizations and Society 23 (8), 813-823.

Barrett, M., Cooper, D. \& Jamal, K. (2005). Globalization and the coordinating of work in multinational audits. Accounting, Organizations and Society, 30(1), 1-24.

Broadbent, J., \& Kirkham, L. (2008). Glass ceilings, glass cliffs or new worlds: Revisiting gender and accounting. Accounting, Auditing \& Accountability Journal, 21(4), 465473.

Ciancanelli, P., Gallhofer, S., Humphrey, C. \& Kirkham, L. (1990) Gender and Accountancy: Some evidence from the UK. Critical Perspectives on Accounting, $1(2), 117-144$.

Cooper, D. J., \& Robson, K. (2006). Accounting, professions and regulation: Locating the sites of professionalization. Accounting, Organizations and Society, 31(4), 415-444.

Crompton, R. (1987). Gender and accountancy: a response to Tinker and Neimark. Accounting, organizations and society, 12(1), 103-110.

Dambrin, C., \& Lambert, C. (2008). Mothering or auditing? The case of two Big Four in France. Accounting, Auditing and Accountability Journal, 21(4), 474-506.

Dambrin, C., \& Lambert, C. (2012). Who is she and who are we? A reflexive journey in research into the rarity of women in the highest ranks of accountancy. Critical Perspectives on Accounting, 23(1), 1-16.

Deif, F. (2008). Perpetual minors: human rights abuses stemming from male guardianship and sex segregation in Saudi Arabia. London: Human Rights Watch. Available at, http://www.hrw.org/reports/2008/04/19/perpetual-minors-0.

Del Castillo D. (2003). Teaching through an electronic veil. The Chronicle of Higher Education, 49(29): http://chronicle.com/article/Teaching-Through-an-Electro/3932/

Doumato, E. A. (1991). Hearing Other Voices: Christian Women and the Coming of Islam. International Journal of Middle East Studies 23 (2), 177-199.

Doumato, E. A. (1992). Gender, Monarchy, and National Identity in Saudi Arabia. British Journal of Middle Eastern Studies 19 (1), 31-47.

Doumato, E. A. (1999). Women and Work in Saudi Arabia: How Flexible Are Islamic Margins? Middle East Journal 53 (4), 568-583.

Doumato, E. A. (2000). Getting God's ear: Women, Islam, and healing in Saudi Arabia and the Gulf. Columbia University Press.

Dwyer, P. D., \& Roberts, R. W. (2004). The contemporary gender agenda of the US public accounting profession: embracing feminism or maintaining empire? Critical Perspectives on Accounting, 15(1), 159-177

Edwards, R. (1990). Connecting method and epistemology: A white women interviewing black women. In Women's Studies International Forum 13(5), 477-490.

Elamin, A. M., \& Omair, K. (2010). Males' attitudes towards working females in Saudi Arabia. Personnel Review, 39(6), 746-766.

Elamin, A. M., \& Alomaim, N. (2011). Does organizational justice influence job satisfaction and self-perceived performance in Saudi Arabia work environment? International Management Review, 7, 38-49.

Emery, M., Hooks, J., \& Stewart, R. (2002). Born at the wrong time? An oral history of women professional accountants in New Zealand. Accounting History, 7(2), 7-34. 
Empson, L. (2004). Organizational identity change: managerial regulation and member identification in an accounting firm acquisition. Accounting, Organizations and Society, 29(8), 759-781.

Fearfull, A., \& Kamenou, N. (2006). How do you account for it? A critical exploration of career opportunities for and experiences of ethnic minority women. Critical Perspectives on Accounting, 17(7), 883-901.

Franks, M. (2002), "Feminisms and Cross-ideological Feminist Social Research: Standpoint, Situatedness and Positionality -Developing Cross-ideological Feminist Research", Journal of International Women's Studies 3(2): 38-50.

Gallagher, E. B., \& Searle, M.C. (1985). Health services and the political culture of Saudi Arabia. Social Science \& Medicine, 21(3), 251-262.

Gallhofer, S. (1998). The silences of mainstream feminist accounting research. Critical Perspectives on Accounting, 9(3), 335-375.

Gammie, E., Gammie, B., Matson, M. and Duncan, F. (2007). Women of ICAS Reaching the Top: The Demise of the Glass Ceiling. The Institute of Chartered Accountants of Scotland, Edinburgh.

Gammie, E., and Whiting, R. (2013). Women accountants: Is the grass greener outside the profession? The British Accounting Review 45, 83-98.

Haniffa, R. and Hudaib, M. (2007). Locating audit expectations gap within a cultural context: The case of Saudi Arabia. Journal of International Accounting, Auditing and Taxation, 16(2), 179-206.

Hamdan, A. (2005). Women and education in Saudi Arabia: Challenges and achievements. International Education Journal, 6(1), 42-64.

Hammond, T. (1997). From complete exclusion to minimal inclusion: African Americans and the public accounting industry, 1965-1988. Accounting, Organizations and Society, 22(1), 29-53.

Hammond, T. (2002). A white-collar profession: African American certified public accountants since 1921. The University of North Carolina Press, Chapel Hill and London.

Haynes, K. (2008). Moving the gender agenda or stirring chicken's entrails? Where next for feminist methodologies in accounting? Accounting, Auditing and Accountability, 21(4), 539-555.

Haynes, K. (2012). Body beautiful? Gender, identity and the body in professional services firms. Gender, Work \& Organization, 19(5), 489-507.

Haynes, K. (2017). Accounting as gendering and gendered: A review of 25 years of critical accounting research on gender. Critical Perspectives on Accounting. 43, 110-124.

Hodges, J. (2017), "Cracking the walls of leadership: women in Saudi Arabia", Gender in Management: An International Journal 32(1): 34-46.

Hubbard, B. (2017). Saudi Arabia agrees to let women drive. The New York Times. Middle East, September, 26.

Hubbard, B. (2017). Saudi Arabia's driving ban and the pioneering women who got it lifted. Independent, Middle East, Wednesday, 18 October.

Hudaib, M. and Haniffa, R. (2009), Exploring auditor independence: an interpretive approach. Accounting, Auditing \& Accountability Journal, 22(2), 221-246.

Hunton, J. E., Neidermeyer, P. E., \& Wier, B. (1996). Hierarchical and gender differences in private accounting practice. Accounting Horizons, 10, 14-31.

Jamjoom, M. I. (2010). Female Islamic studies teachers in Saudi Arabia: a phenomenological study. Teaching and Teacher Education, 26(3), 547-558.

Jerichow, A. (1998). The Saudi File. New York: St. Martin's Press. 
Kamla, R. (2012) Syrian women accountants' attitudes and experiences at work in the context of globalization. Accounting, Organizations and Society, 37(3), 188-205.

Karam, A. M. (1998). Women, Islamisms and the state: Contemporary feminisms in Egypt. London: Macmillan Press Ltd.

Khalifa, R. (2013). Intra-professional hierarchies: the gendering of accounting specialisms in UK accountancy. Accounting, Auditing \& Accountability Journal, 26(8), 12121245.

Kim, S.N. (2004a). Imperialism without empire: Silence in contemporary accounting research on race/ethnicity. Critical Perspectives on Accounting, 15(1), 95-133.

Kim, S. N. (2004b). Racialized gendering of the accountancy profession: toward an understanding of Chinese women's experiences in accountancy in New Zealand. Critical Perspectives on Accounting, 15(3), 400-427.

Kinninmont, J. (2017). Vision 2030 and Saudi Arabia's Social Contract Austerity and Transformation. In Research Paper: Middle East and North Africa Programme, Chatham House, The Royal Institute of International Affairs, Great Britain.

Kirkham, L. M. (1992). Integrating herstory and history in accountancy. Accounting, Organizations and Society, 17(3), 287-297.

Kirkham, L. M., \& Loft, A. (1993). Gender and the construction of the professional accountant. Accounting, Organizations and Society, 18(6), 507-558.

Kirton, G. and A.-M. Greene (2015). The Dynamics of Managing Diversity: A Critical Approach, Fourth Edition, London, Routledge.

Komori, N. (2007). The "hidden" history of accounting in Japan: a historical examination of the relationship between Japanese women and accounting. Accounting History, 12(3), 329-358.

Komori, N. (2008). Towards the feminization of accounting practice: lessons from the experiences of Japanese women in the accounting profession. Accounting, Auditing \& Accountability Journal, 21(4), 507-538.

Kornberger, M., Carter, C., \& Ross-Smith, A. (2010). Changing gender domination in a Big Four accounting firm: Flexibility, performance and client service in practice. Accounting, Organizations and Society, 35(8), 775-791.

KSU - King Saud University Profile Report (2012). https://cba.ksu.edu.sa/sites/cba.ksu.edu.sa/files/imce_images/annual_report_mis_2 014-15.pdf

Lehman, C. R. (1992). "Herstory" in accounting: The first eighty years. Accounting, Organizations and Society, 17(3), 261-285.

Loft, A. (1992). Accountancy and the gendered division of labour: a review essay. Accounting, Organizations and Society, 17(3), 367-378.

Lupu, I. (2012). Approved routes and alternative paths: The construction of women's careers in large accounting firms. Evidence from the French Big Four. Critical Perspectives on Accounting, 23(4), 351-369.

Maupin, R. J. \& Lehman, C. R. (1994). Talking heads: stereotypes, status, sex-roles and satisfaction of female and male auditors. Accounting, Organizations and Society, 19(4), 427-437.

McKeen, C. A. and A. J. Richardson (1998). Education, employment and certification: An oral history of the entry of women into the Canadian accounting profession. Business and Economic History, 27(2), 500-521.

McNicholas, P., et al. (2004). Maintaining the empire: Maori women's experiences in the accountancy profession. Critical Perspectives on Accounting, 15(1), 57-93.

Mellahi, K. (2007). The effect of regulations on HRM: private sector firms in Saudi Arabia. The International Journal of Human Resource Management, 18(1), 85-99. 
Metcalfe, B. D. (2007). Gender and human resource management in the Middle East. The International Journal of Human Resource Management, 18(1), 54-74

Mihret, G.D.; Alshareef, M.N.; and Bazhair, A. (2017). Accounting professionalization and the state: The case of Saudi Arabia. Critical Perspectives on Accounting, 45, 29-47.

Mobaraki, A. H. \& Söderfeldt, B. (2010). Gender inequity in Saudi Arabia and its role in public health. Eastern Mediterranean Health Journal, 16(1), 113-118.

Mosquera, P. M. R., Manstead, A. S., \& Fischer, A. H. (2002). Honour in the Mediterranean and Northern Europe. Journal of Cross-Cultural Psychology, 33(1), 16-36.

Muzio, D., \& Tomlinson, J. (2012). Editorial: Researching Gender, Inclusion and Diversity in Contemporary Professions and Professional Organizations. Gender, Work \& Organization, 19(5), 455-466.

Reed, S. A., Kratchman, S. H., \& Strawser, R. H. (1994). Job satisfaction, organizational commitment, and turnover intentions of United States accountants: The impact of locus of control and gender. Accounting, Auditing \& Accountability Journal, 7(1), 31-58.

Roberts, J. \& Coutts, J. A. (1992). Feminization and professionalization: a review of an emerging literature on the development of accounting in the United Kingdom. Accounting, Organizations and Society, 17(3), 379-395.

Shackleton, K. (1999). Gender segregation in Scottish chartered accountancy: the deployment of male concerns about the admission of women, 1900-25. Accounting, Business \& Financial History, 9(1), 135-156.

Schlaffer, E. \& Kropiunigg, U. (2011). Saudi Youth: Unveiling the Force for Change. Centre for strategic and international studies, Middle East program.

Sidani, Y. (2005). Women, work, and Islam in Arab societies. Women in Management Review, 20(7), 498-512.

SOCPA (2013). Saudi Organization for Certified Public Accountants. https://socpa.org.sa

SOCPA (2018). Saudi Organization for Certified Public Accountants. https://socpa.org.sa

Syed, J., F. Ali and S. Hennekam (2018), "Gender equality in employment in Saudi Arabia: a relational perspective", Career Development International 23(2): 163-177.

Woodworth, B. and Said, K.E. (1996). Internal auditing in a multicultural environment: the Saudi Arabia experience. Managerial Auditing Journal, 11(2), 20-27.

Windsor, C. and P. Auyeung (2006). The effect of gender and dependent children on professional accountants' career progression. Critical Perspectives on Accounting 17(6), 828-844.

Wirth, L. (2001). Breaking through the glass ceiling: women in management. Geneva, International Labour Office.

Whiting, R. H. (2012). Reflecting on perceived deinstitutionalization of gender-biased employment practices in accountancy. Qualitative Research in Accounting \& Management, 9(4), 300-336.

Young, K.E. (2016). Women's labour force participation across the GCC. The Arab Gulf States Institute in Washington - building bridges and understanding. Issue Paper.

Zahidi, S., Geiger, T. and Crotti, R. (2018). The Global Gender Gap Report 2018. Geneva: World Economic Forum. 